\title{
The diopter
}

\author{
Paulus T. V. M. de Jong $\mathbb{D}^{1,2}$
}

Received: 6 December 2020 / Revised: 12 December 2020 / Accepted: 15 January 2021 / Published online: 2 February 2021

(c) The Author(s), under exclusive licence to The Royal College of Ophthalmologists 2021

Diopter, in the sense of telescope [1], sparked off this article. According to several dictionaries, diopter is derived from the Greek dioptra [2-4]. A dioptra is an optical instrument for measuring angles or altitudes [5] invented by the Greek astronomer Hipparchus, 150 BC [4]. Perhaps dioptra can be traced back to the Greek dia opteuo, through seeing [5]. Also in Latin, diopter is called dioptra [6].

In 1834, Stampfer wrote that he used several diopters or telescopes while performing experiments on the accuracy of sights when measuring angles [1]. It thus seems that at that time a diopter was similar to a telescope and this is in accordance with a comment that a diopter is a "long tube, employed by Arabian astronomers to the extremities of which ocular and object diopters were attached" [2]. The Oxford dictionary thus mentions an author, equating a diopter with a lens. This dictionary also cites as meanings for diopter, an ancient theodolite, the index arm of a graduated circle, a surgical speculum, an instrument for obtaining drawings of the skull by projections, before arriving at "a unit of measurement for lenses" [2]. Donders did not use the word diopter in his famous book, published by the New Sydenham society, in which he classified refraction anomalies [7] but he did write about the dioptric power of lenses, that he expressed in Paris feet or inches. When then, did one first formulate our current concept of the diopter as the unit of refractive power of a lens?

In 1790, after the French revolution, a commission of the French Academy of Sciences advised to adopt the decimal system and the meter. At the time, almost every major European city had a different length for its foot or inch unit

Paulus T. V. M. de Jong

p.dejong@nin.knaw.nl

1 Department of Retinal Signal Processing, The Netherlands Institute for Neuroscience, KNAW, Amsterdam, The Netherlands

2 Department of Ophthalmology, Amsterdam UMC, University of Amsterdam, Amsterdam, The Netherlands
[8]. In 1799, the meter became the French standard. During the 3rd International Congress of Ophthalmology in Paris in $1867[9,10]$, one set up a commission "to consider the best means for substituting the meter for the foot in the measurement of defects of refraction and accommodation". The French-German war of 1870-1871, during which the commission could not meet, delayed the work of the committee and the presentation of its report before the 4th International Congress in London in 1872. The commission reported at this 4th congress, that all members agreed that the foot should be substituted for the meter and that lenses should be numbered according to their focal length and not according to the radius of their curvature, as was the custom [10]. Javal proposed as the lens representing unity, on behalf of the commission, a biconvex Crown glass lens of 96-inch radius of curvature, leading to a focal length of $240 \mathrm{~cm}$. He was prompted to choose this lens by his wish to conform to Donders' s lens power calculations in Paris inches [10]. Nagel (Fig. 1), also in the commission, did not agree and proposed "To accept a lens of $1 \mathrm{~m}$-focus, to be called the meter-lens, as a base for a set of glasses and as a

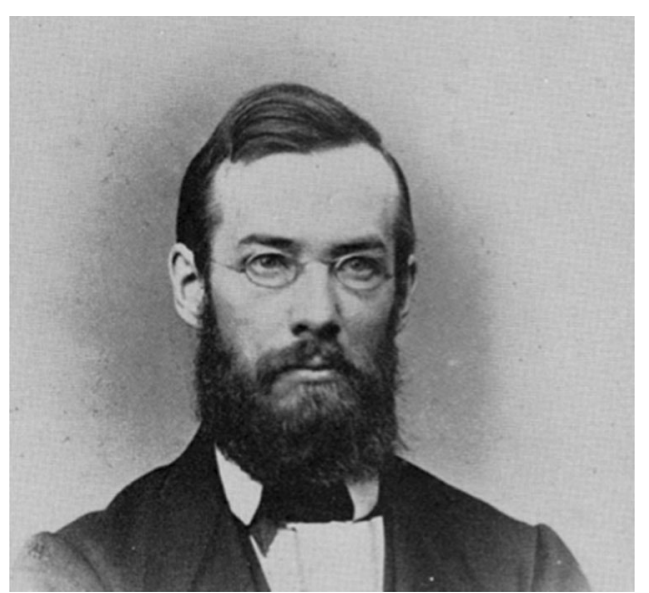

Fig. 1 Albrecht Nagel, 1833-1895. He studied at the University of Königsberg under von Helmholtz, in Berlin as a pupil of von Graefe, with Donders in Utrecht and worked from 1874 to 1895 as the first professor of ophthalmology in Tübingen [17]. 


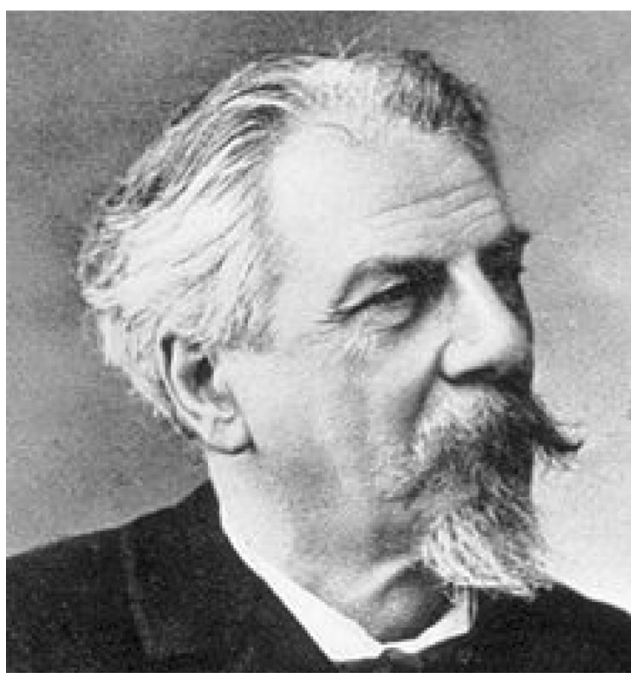

Fig. 2 Ferdinand Monoyer, 1836-1912. As a widow, his mother remarried Prof. Stoeber from Strasbourg when Ferdinand was 5 years old. Ferdinand studied medicine, married his stepsister Jeanne and worked in his stepfather's clinic. In 1870, he became head of the ophthalmology clinic at the newly established medical school in Nancy. From 1878 until his death, he worked as professor of medical physics in Lyon $[12,18]$.

unit for their determination" [11]. Javal's proposal was supported by 48 participants, among whom Bowman, De Wecker, and Donders [10]. This proposal shocked Ferdinand Monoyer (Fig. 2), Hischberg mistakenly called him Felix Monoyer [12], who by the way, had translated Donders' s book on refraction anomalies in French [13]. Monoyer wrote earlier that a focal length of $100 \mathrm{~cm}$ should be the basis for the metric system [14]. He responded to Javal's suggestion by writing (in French)...."if I had been able to attend the Congress, I would have fought with all my might the adoption of the optical unit chosen by Javal" [9]. Thus, Monoyer agreed with a fixed focal length but calculated that with the $240 \mathrm{~cm}$ as proposed by Javal, opticians would have to use 38 extra trial lenses. As a simple solution, Monoyer again proposed to take as unit of refraction the power of a standard lens with a focal distance of $100 \mathrm{~cm}$ and to express the refractive power of any other lens by an integer representing the number of refracting units. Monoyer wrote in French "We will call this lens a metric or decimal unit of refraction, or simply Dioptrie, if we may be permitted to use this neologism in accordance with scientific usage" [9]. Some people think that Monoyer derived Dioptrie from Kepler's Dioptrice [15], a neo-Latin word derived from the Latin dioptra.

Nagel agreed with Monoyer on a $1 \mathrm{~m}$ focal length for the standard lens. He stated that in America "one will hardly want to decide on this question" and praised Monoyer for his foray into showing the absurdity of Javal's proposal, by writing "if one kept Javal's $240 \mathrm{~cm}$, then one should also define the calorie as a unit with that energy that heats $240 \mathrm{~cm}^{3}$ of water 1 degree" [11]. Nagel disagreed with Giraud-Teulon who opted for a $2 \mathrm{~m}$ lens and Burow who choose a $3 \mathrm{~m}$ lens as refraction unit. Because Nagel thought that $1 \mathrm{~m}$ lenses in practice formed too large refractive steps and that one had to work also with $1 / 2 \mathrm{~m}, 1 / 4 \mathrm{~m}$, or even smaller fractions of lenses, Monoyer accused him of lese majesty of the decimal system [11]. Nagel considered the term diopter, used by Monoyer, superfluous "as it did not mean anything in particular and because people already started to use demi-diopters and diopters décamétriques" [11].

However, 2 years later Nagel mentioned at the 5th International Congress in New York that the lens of $1 \mathrm{~m}$ focus was widely used in Europe and wrote "A declaration of opinion by the Congress, particularly if it should be unanimous and without opposition, would strongly promote the reform. All that needs to be done is to establish this one principle, viz., that henceforth all lenses, spherical and cylindrical, shall in regard to their refraction be denominated in such a way that the lens of $1 \mathrm{~m}$-focus (to be called the meter-lens, or if so desired Dioptrie) is taken as a unit......" [16]. Therefore, it took two millennia, before Monoyer with Nagel's help changed the meaning of the word diopter from a see-through device to its most common current meaning: the unit of the refractive power of a lens or a curved mirror.

Acknowledgements I am deeply indebted to P. Stoutenbeek MD, ophthalmologist, who spent a considerable amount of his precious time discussing neo-Latin and optical issues.

\section{Compliance with ethical standards}

Conflict of interest The author declares that he has no conflict of interest.

Publisher's note Springer Nature remains neutral with regard to jurisdictional claims in published maps and institutional affiliations.

\section{References}

1. Stampfer S. Ueber die Genauigkeit des Visirens bei Winkelmessungen. Jahrbücher des kk polytechnischen Institutes in Wien. Wien: Gerold; 1834. p. 211-36.

2. Unknown. Oxford English Dictionary online. 2020. https://www. oed.com.

3. Dorland's illustrated medical dictionary. 28th ed. Philadelphia: Saunders; 1994.

4. Webster's new twentieth century dictionary of the English language. 2nd ed. USA: Collins; 1980.

5. Liddell HG, Scott R. A Greek-English lexicon. Oxford: Oxford University Press; 1990.

6. Lewis CT, Short C. A Latin Dictionary. New York: Oxford University Press; 1989.

7. Donders FC. On the anomalies of accommodation and refraction of the eye. London: New Sydenham Society; 1864. p. 635.

8. Foot (unit). 2020. https://en.wikipedia.org/wiki/Foot_(unit). 
9. Monoyer F. Sur 1 'introduction du systeme métrique dans le numérotage des verres de lunnette, et sur le choix d'une unité de réfraction. Ann Ocul. 1872;68:105-17.

10. Javal E. On the advisability of adopting the metrical system for estimating the amount of ametropia. Report of the fourth International Ophthalmological Congress, held in London, August 1872. Edwards and co; 1873. p. 147-73.

11. Nagel A. Ueber die Benutzung des Metermasses zur Numerirung der Brillen. Klin Mbl Augenheilk. 1874;12:362-79.

12. Hirschberg J. Die Augenheilkunde in der Neuzeit. Die Reform der Augenheilkunde II. Felix Monoyer (1836-1912). GraefeSaemisch Handbuch der gesamten Augenheilkunde. 15-2. Leipzig: Engelmann; 1916. p. 582.

13. Monoyer F. Les anomalies de la réfraction de l'oeil et leurs suites, par F.C.Donders, traduction faite sous les yeux de 1 'auteur par le Dr F. Monoyer. Paris: Bailliere; 1865.
14. Monoyer F. Des anomalies de la réfraction de l'oeil. Notions théoriques et observations cliniques, 1er partie. Strasbourg: Gazette médicale de Strasboug; 1868.

15. Kepler J. Dioptrice seu demonstratio eorum quae visui \& visibilibus propter conspicilla non ita pridem inventa accidunt. Augsburg: Francus; 1611. p. 83.

16. Nagel A. The introduction of the meter-measure for the determination of lenses. Report of the fifth International Ophthalmological Congress, held in New York, September 1876. New York: Appleton; 1877. p. 66-7.

17. Hirschberg J. Die Augenheilkunde in der Neuzeit. Die Reform der Augenheilkunde II. Albrecht Nagel. 3-2. Leipzig: Engelmann; 1916. p. 288-93.

18. Unknown. Ferdinand Monoyer, l'inventeur de la dioptrie pour mesurer l'acuité visuelle: Le Progres; 2015. https://fr.wikipedia. org/wiki/Ferdinand_Monoyer. 